\title{
The Impact of Oil Price Changes on FTSE/JSE Industry Indices Performance
}

\author{
Eddson Zengeni and Mashukudu Hartley Molele*
}

Wits Business School, 2 St Davids PI \& St Andrew Rd, Parktown, Johannesburg, 2193, South Africa

\begin{abstract}
The impact of oil price changes on stock market index of the JSE, South Africa, was examined using NARDL model using 2008 -2017 monthly data of aggregated industrial indices. All-Share index was incorporated in the estimation equation to represent market factors.

The results indicate that in the short-term, the indices responded asymmetrically to oil price changes whilst in the long-term they responded symmetrically. Oil \& Gas, Industrials, Consumers services and Technology indices followed oil price change direction whereas Consumer goods and Financials indices opposed oil price change direction. Healthcare and Telecommunications responded in one direction irrespective oil price change direction.
\end{abstract}

Keywords: Non-linear ARDL, Oil prices, Stock Market index, JSE.

\section{INTRODUCTION}

Extensive research has been conducted to understand the impact of oil price changes on macroeconomic factors (Batac \& Tatlonghari, 2013; Hussin, Muhammad, Hussin, \& Razak, 2012; Sahu \& Mondal, 2015; Sedick, 2016; Wong \& El Massah, 2017). Most of these were predominantly based on static techniques lacking the capability for simultaneous long-term and short-term relationship evaluation nor distinguishing between positive and negative changes.

Research efforts to establish the impact of oil prices changes on stock market performance have yielded contradictory findings, e.g. for South African alone, one group of researchers found minimal impact of oil price changes on stock markets (Chinzara, 2011) yet another group reported a positive relationship between world oil price changes and stock prices (Chisadza, Dlamini, Gupta, \& Modise, 2016).

Oil price changes have varying economic performance impact on oil exporting countries compared to oil importing countries. For oil exporting mono-structured economies, like Nigeria, economic performance follows oil prices change direction due to impact on export revenue (Adetunji Babatunde, Adenikinju, \& Adenikinju, 2013). However, oil importing countries like South Africa performance opposes the oil price change direction. Increase in oil price leads to cost of production increase resulting in companies reducing their production output to reduce cost if prices are maintained the same. In the event of increased prices to offset the increased cost of production, demand for the products will decrease. (Sahu \& Mondal, 2015). Figure 1 shows the historic performance of the nine industry indices on the JSE over the 10 year period under evaluation.

*Address correspondence to this author at the Wits Business School, 2 St Davids PI \& St Andrew Rd, Parktown, Johannesburg, 2193, South Africa; E-mail: mhmolele@gmail.com
This understanding on the impact of oil price changes on macroeconomic variables such as GDP growth (Balcilar, van Eyden, Uwilingiye, \& Gupta, 2017; Lardic \& Mignon, 2008), exchange rate (Adebiyi, Adenuga, Abeng, \& Omanukwue, 2009; Hussin et al., 2012; Iheanacho, 2016; Lawal, Somoye, \& Babajide, 2016; Sahu \& Mondal, 2015; Sedick, 2016) and inflation (Cologni \& Manera, 2008; Cunado \& De Gracia, 2005; Duma, 2008; Lacheheb \& Sirag) prompted the need to understand whether oil price changes have impact on stock market performance. Researchers have since used various methods to evaluate this impact at different levels of the stock market (Maghyereh, 2006; S. Mohanty, Nandha, \& Bota, 2010; Ogiri, Amadi, Uddin, \& Dubon, 2013; Salisu \& Oloko, 2015; Scholtens \& Yurtsever, 2012; Shammas, 2012; Zhang \& Chen, 2011; Zhu, Li, \& Yu, 2011)

There remains the need to understand how various stock market industries are impacted by oil price changes and whether this impact is long-term or short-term and how symmetrical is it. Looking at typical historical relationship between oil price and two of South African industry indices, Figure $\mathbf{2 a}$ and $\mathbf{b}$, it appears that Basic Materials (J510) are highly impacted by oil price changes than Consumer goods (J530) industry. These high-level observations cement the need to understand variations of oil price change impact on different industries.

This research seeks to investigate the impact of oil price changes on industry performance in the South African context as measured by stock market performance using a newly developed dynamic method, the NARDL.

The method allows to evaluate the impact of oil price changes in both the short-term and long-term and whether these changes price have symmetrical effect on the performance on industry performance. The 


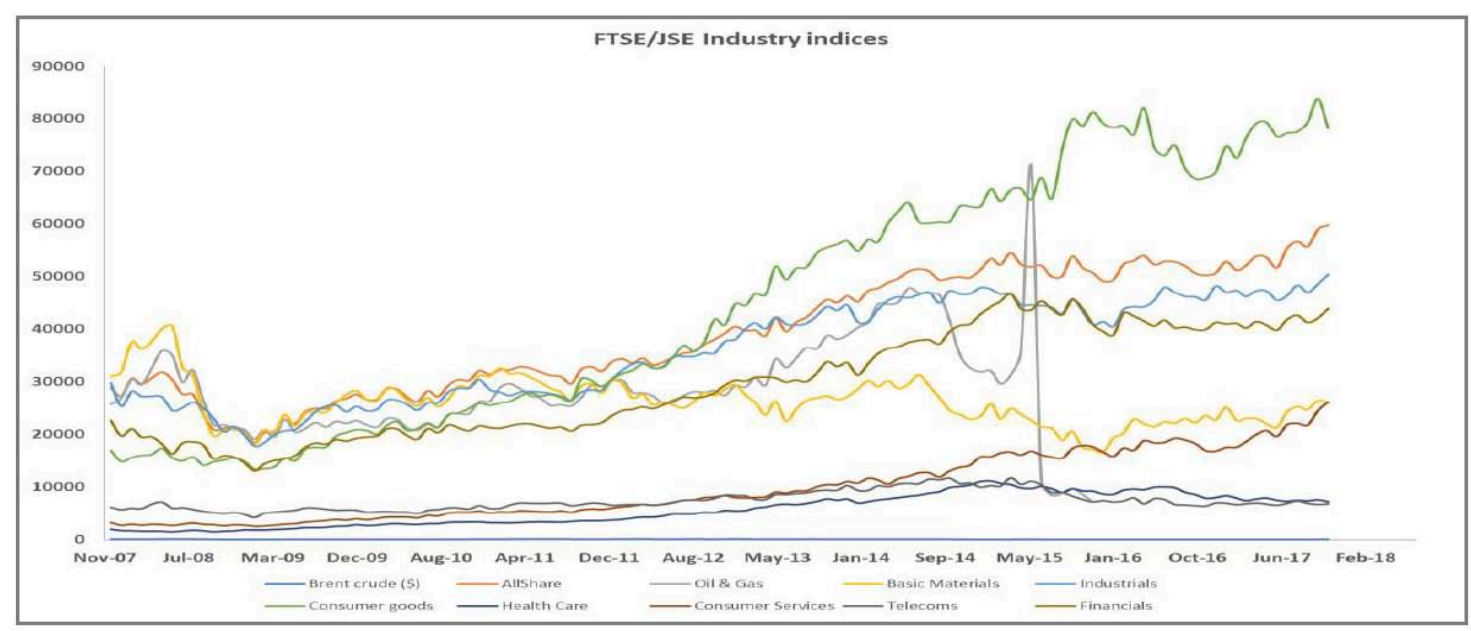

Figure 1: Performance of FTSE/JSE industry indices between Dec 2007 and Nov 2017.

Source: IRESS.
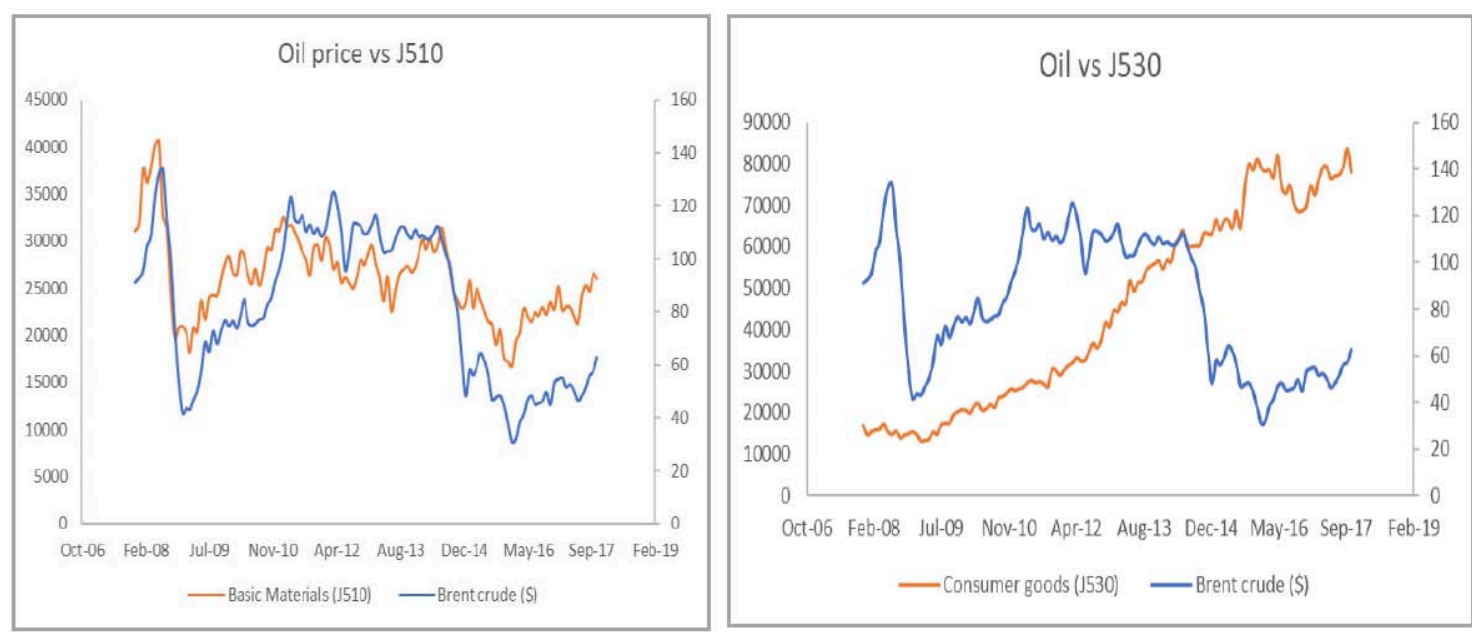

Figure 2: (a) FTSE/JSE Basic Materials J510 index and (b) FTSE/JSE Consumer Goods J530 index vs oil price between Dec 2007 and Nov 2017.

Source: IRESS.

method provide a multi-dimensional view which is not offered by traditional static methods.

\section{LITERATURE REVIEW}

Oil is one of the most critical commodities used in today's world economy. It is used as a major input in petroleum products and by-products of its refinement find use in industries such as chemicals, plastics and electricity generation (Duma, 2008; Sukati, 2013). However, oil price depends on a variety of factors including, market demand, quantity produced, available reserves and geopolitical situation. Researchers have developed increasingly interested on how oil price changes affect economic performance.

An article by Hamilton (1983) on how all US recessions have been preceded by oil price shocks since World War II sparked research on the impact between oil price changes and macroeconomic factors among researchers (Beckmann, Czudaj, \& Arora,
2017; Brown \& Yücel, 2002; Burbidge \& Harrison, 1984; Chou \& Tseng, 2016; Cologni \& Manera, 2008; Cunado \& De Gracia, 2005; Cuñado \& de Gracia, 2003; Du, Yanan, \& Wei, 2010; Hamilton \& Herrera, 2004; Hooker, 1996; Iheanacho, 2016; B. R. Lee, Lee, \& Ratti, 2001; K. Lee, Ni, \& Ratti, 1995; Mork, 1989; Mork, Olsen, \& Mysen, 1994; Moya-Martínez, Ferrer-Lapeña, \& Escribano-Sotos, 2014; Tang, Wu, \& Zhang, 2010). Mork et al. (1994) demonstrated that there was a clear negative correlation between oil price and measures of output or employment after reviewing research findings that followed Hamilton's work.

\subsection{Theory of Stock Valuation and Impact of Oil Price}

Theoretically oil price volatility impact stock market performance through economic factors such as inflation, interest rates, costs of production, income, economic growth (Moya-Martínez et al., 2014). The Arbitrage Pricing Theory (APT), according to Ross 
(1976), provides the theoretical background through which multifactor framework is factored into stock market price determination and volatility mechanism (Larsson \& Haq, 2016; Ross, 2013).

Micro-based asset pricing models show that there are two types of factors which affect the value of a stock, Firstly, macroeconomic factors such as the foreign exchange rate, interest rate, stock market volatility (or market risk), stock market liquidity, economic growth, industrial production, and factors affecting current and future consumption (Breeden, 2005; Cochrane, 1991; Lintner, 1975; Merton, 1973; Sharpe, 1964; Stulz, 1981). Second type is the portfolio characteristic factors, which include the rate of stock return, the variance of stock return, dividends or earnings, book to market ratios, and the company size (Fama, 1965; Malkiel \& Fama, 1970; Ross, 2013).

Economic theory suggests that current stock prices reflect the discounted future cash flows of a particular stock (Degiannakis, Filis, \& Arora, 2017; R. D. Huang, Masulis, \& Stoll, 1996). This can be shown as:

$P_{i, t}=\sum_{n=t+1}^{N}\left(\frac{E\left(C F_{n}\right)}{(1+E(r))^{n}}\right)$

Where:

$C F_{n}$ is the cash flow at time $n$

$r$ is the discount rate.

\section{$E(*)$ denotes the expectation operator}

This equation illustrates that stock returns are impacted by factors that can influence expected cash flow and discount rate.

One such factor can be oil price which in theory affects stock returns in two ways

1. Increase in oil price results in increased cost of production, especially for oil-importing countries. The increased cost of production reduces company earnings (if prices are maintained). Increasing product price to offset increasing production costs will cause a decrease in product demand resulting in reduced earnings for the company.

2. Increase in oil price may lead to increased inflation leading to increased interest rates which translate to increased discount rate

\subsection{Impact of Oil Price Changes on Stock Markets Performance}

Research on the impact of oil price on stock markets only emerged following reserachers' findings on the impact of oil price changes on macroeconomic factors. Some studies reported a negative impact of oil price changes on stock market performance (Aloui \& Jammazi, 2009; Asteriou \& Bashmakova, 2013; Bachmeier, 2008; Chen, 2009; Cifarelli \& Paladino, 2010; Ciner, 2001, 2013; Driesprong, Jacobsen, \& Maat, 2008; Filis, 2010; Filis \& Chatziantoniou, 2014; Gjerde \& Saettem, 1999; Henriques \& Sadorsky, 2008; R. D. Huang et al., 1996; Jones \& Kaul, 1996; Laopodis, 2011; Y.-H. Lee \& Chiou, 2011; Miller \& Ratti, 2009; Nandha \& Faff, 2008; O'Neill, Penm, \& Terrell, 2008; Papapetrou, 2001; Park \& Ratti, 2008; Sadorsky, 1999, 2001) whilst others reported oil price changes positively impacting stock market performance (Arouri \& Rault, 2012; El-Sharif, Brown, Burton, Nixon, \& Russell, 2005; Lescaroux \& Mignon, 2008; Li, Zhu, \& $\mathrm{Yu}, 2012$; Zhu et al., 2011). The matter is further complicated by some researcher who reported lack of meaningful link between oil price changes and stock market performance (Cong, Wei, Jiao, \& Fan, 2008; R. D. Huang et al., 1996; S. Mohanty et al., 2010; Sari, Hammoudeh, \& Soytas, 2010). The differences in findings can be attributed to complexity of factors considered when evaluating the impact of oil prices;

The nature of the country studied i.e. the results may differ between oil-exporting and oil-importing countries (Creti, Ftiti, \& Guesmi, 2014). The literature reviewed so far appear to indicate that there is a positive relationship between oil price and stock markets in purely oil-exporting countries but varying findings when oil-importing countries are considered

Model used in the study, as linear based models tend to be static and miss the non-linear component of the impact (Beckmann et al., 2017). Many studies on oil price modelling have been conducted in a linear framework yet consideration of non-linear effects appear logical given that various shareholders have different investment timeframes. Furthermore, an investor may be interested in understanding which changes increase risk exposure between positive changes and negative changes.

Impact timeframe, as long-term study is likely to yield results different from those of short-term studies

Symmetrical analysis whereby negative changes are likely to have different impact than positive changes. In the literature reviewed, the phenomenon of asymmetry effect has been explored by some researchers and found to exist between oil price and stock markets (Basher \& Sadorsky, 2006; Perdiguero-García, 2013; Sadorsky, 1999; Salisu \& Oloko, 2015). 


\subsection{Impact of Oil Price on Sector/Industry Level Stocks}

Most of early studies conduct on oil price changes-stock market performance relationship focused on aggregated stock markets. Those that looked at sector based stocks concentrated on the oil and gas sector (Aleisa \& Dibooglu, 2004; Boyer \& Filion, 2007; Dayanandan \& Donker, 2011; El-Sharif et al., 2005; Ghouri, 2006; Lanza, Manera, Grasso, \& Giovannini, 2005) and the airline and the transportation sectors (S. K. Mohanty \& Nandha, 2011; Morrell \& Swan, 2006). Logically these are sectors which appear to be closely linked to the oil industry hence the oil price. These prior studies ignored the less- and the non-oil-intensive sectors such as the industrials and the services sectors (Arouri \& Rault, 2012) with the exception of Mohanty et al.(S. Mohanty et al., 2010)

A European sector based study found that oil price have significant impact on the various European markets but the magnitude and the direction of the impact varies between different sectors (Arouri \& Nguyen, 2010). Similar observations were made on US based study on sectoral level (Malik \& Ewing, 2009). These results seem to make logical sense since oil is an input to many production process, it can be expected that sectors would be impacted different, either based on their nature (i.e. oil consumption or oil production) based on the extend of linkage to the oil industry and oil consumption requirements.

From the sectoral based studies conducted so far, the Oil \& Gas sector followed the direction on oil price changes, whilst the reverse holds true for all the other sectors. This points towards the understanding that oil price increases have a positive impact on oil-related and oil-substitute sectors, a negative effect on oil-using sectors and no significant effect on non-oil related sectors (such as those dominated by services companies) (Broadstock \& Filis, 2014).

\subsection{Econometric Models}

Until recently, the most commonly used models reported in literature have been linear in nature The shortcomings of linear models have been highlighted in their inability to neither detect non-linear relationships between variables nor capture asymmetric behaviour between variables over time. Non-linear relationships have been reported between oil price and stock markets (An, Gao, Fang, Huang, \& Ding, 2014; X. Huang, An, Gao, Hao, \& Liu, 2015; Ma, Wei, Huang, \& Zhao, 2013; Vacha \& Barunik, 2012).

On the other hand, NARDL model by Shin et al. in 2014 was developed by extending the ARDL model to produce a fully dynamic model. It is a flexible dynamic parametric framework with which to model relationships that exhibit combined long- and short-term asymmetries. It uses positive and negative partial sum decompositions in detecting the asymmetric effects in the long-term and the short-term periods. The key advantages of this model over the traditional cointegration models includes (Shin, Yu, \& Greenwood-Nimmo, 2014);

Better performance compared to the classical cointegration models

It is applicable to regressors that are stationary at level of first difference (i.e. I(0) or I(1)) and,

Has the ability to detect hidden cointegration

The impact of oil price changes on stock market performance remains a complex issue given all these factors that needs to be considered in the analysis. It is therefore critical to utilise a model that covers the parameters that impact the results of the study. As such, the NARDL model presents an opportunity for dynamic analysis on the impact of oil prices changes on stock market performances.

\section{METHODOLOGY AND DATA}

The oil price used in this study was the price of Brent Crude oil (in USD) on the international market. A brief description of the industry indices is provided in Table 1 whilst the detailed description is provided in Appendix A (see supplementary information).

Monthly historical data for Brent crude oil for the period Dec 2007 to Nov 2017 was obtained from SARB database. Monthly historical data for nine of the FTSE/JSE industry indices was obtained from IRESS (2018) through INERT BTA for the period Dec 2007 and Nov 2017. The FTSE/JSE Utilities index J507 was not used in this study due to its small size and low trading data. On the other hand, the FTSE/JSE Oil \& Gas index was not included in this study due to lack of sufficient data caused by changes that took place during the period of study.

\subsection{Data Analysis Methodology}

The NARDL approach used in this study is an extension of the linear ARDL approach which was proposed by Pearson et al. in 2001. To better understand NARDL, the generalised linear ARDL is explained first. The linear ARDL model is an equation that evaluates relationship between two or more variables as stated by the researcher. Equation 1 represent the linear ARDL model (M Hashem Pesaran, Yongcheol Shin, \& Richard J Smith, 2001) which tries 
Table 1: Brief Description of the JSE Industry Indices

\begin{tabular}{|c|c|c|}
\hline FTSE/JSE Code & Index Name & Description \\
\hline $\mathrm{J} 203$ & All-Share & The all index comprises the entire stock indices of the JSE \\
\hline $\mathrm{J} 500$ & Oil \& Gas & CompaJ500Jnies that are in the oil and gas value chain \\
\hline $\mathrm{J} 510$ & Basic Materials & Companies in the chemicals and basic resources. \\
\hline J520 & Industrials & Companies in construction \& materials and Industrial goods \& services \\
\hline $\mathrm{J} 530$ & Consumer Goods & $\begin{array}{c}\text { Made up of automotive \& parts, food \& beverages and personal \& household } \\
\text { goods }\end{array}$ \\
\hline $\mathrm{J} 540$ & Health Care & Consists of health care equipment \& services \\
\hline $\mathrm{J} 550$ & Consumer Services & Consists of the retail and media \\
\hline J560 & Telecommunications & Companies in fixed line and mobile telecommunications business. \\
\hline $\mathrm{J} 580$ & Financials & Made up of Banks, Insurance, Real Estate and Financial Services. \\
\hline J590 & Technology & $\begin{array}{c}\text { Consists of businesses in software \& computer services and technology hardware } \\
\qquad \& \text { equipment }\end{array}$ \\
\hline
\end{tabular}

to capture relationship between variables in the form of $Y=f(X)$

$$
\Delta Y_{t}=\alpha_{0}+\alpha Y_{t-1}+\alpha_{2} X_{t-1}+\sum_{i=1}^{k} \beta_{i} \Delta Y_{t-i}+\sum_{j=0}^{l} \theta_{j} \Delta X_{t-j}+\varepsilon_{t}
$$

Where:

$X_{t}$ is the logarithm of independent variable (e.g. crude oil prices)

$Y_{t}$ is the logarithm of the dependent variables (e.g. All-Share index)

\section{$\alpha_{1}$ and $\alpha_{2}$ are long-term coefficients \\ $\beta_{i}$ and $\theta_{j}$ are short-term coefficients}

$k$ and I are the optimal lags for the first differences of variables selected by Schwartz Information Criterion (SIC) and Akaike Information Criterion (AIC).

The term $\varepsilon_{t}$ is the white noise error

In the linear ARDL model, the long-term relationship between the variables is established by testing the null hypothesis of no cointegration $\left(\alpha_{1}=\alpha_{2}=0\right)$

The NARDL model makes use of positive and negative partial sum decompositions in detecting the asymmetric effects in the long-term and short-term periods (Shin et al., 2014). NARDL can analyse the presence of asymmetry in non-stationary variables, therefore it is suitable for exploring price series because they are usually non-stationary.

The approach used in this study follows a similar one utilised by Kisswani and Elian (Kisswani \& Elian, 2017) by first hypothesising the long-term equation of indices as follows:
$Y_{t}=\alpha_{0}+\alpha_{1} J 203_{t}^{+}+\alpha_{2} J 203_{t}^{-}+\alpha_{3} B C O_{t}^{+}+\alpha_{4} B C O_{t}^{-}+$

$\varepsilon_{t}$

Where:

$Y_{t}$ is the index price

$\mathrm{BCO}$ is the Brent Crude Oil price

J203 is the All-Share Index used to factor out market influence

$\alpha=\left(\alpha_{0}, \alpha_{1}, \alpha_{2}, \alpha_{3}, \alpha_{4}\right)$ is the cointegration vector or vector of long-term parameters to be estimated

$\varepsilon_{t}$ is the noise factor

The non-linear cointegration regression is represented as:

$Y_{t}=\delta^{+} B C O_{t}^{+}+\delta^{-} B C O_{t}^{-}+\pi_{t}$

Where $\delta^{+}$and $\delta^{-}$are the associated long-term parameters and $\mathrm{BCO}_{t}$ is a $\mathrm{K} \times 1$ vector of regressors

$\mathrm{BCO}_{t}^{+}$and $\mathrm{BCO}_{t}^{-}$are the partial sums of positive and negative changes in oil prices:

$$
\begin{aligned}
& B C O_{t}^{+}=\sum_{i=1}^{t} \Delta B C O_{i}^{+}=\sum_{i=1}^{t} \max \left(\triangle B C O_{i}, 0\right) \\
& B C O_{t}^{-}=\sum_{i=1}^{t} \Delta B C O_{i}^{-}=\sum_{i=1}^{t} \max \left(\triangle B C O_{i}, 0\right)
\end{aligned}
$$

Using these four equations (2-5), the linear model is modified to account for asymmetries thus producing the non-linear ARDL model:

$Y_{t}=\alpha_{0}+\alpha_{1} Y_{t-1}+\alpha_{2}^{+} B C O_{t-1}^{+}+\alpha_{2}^{-} B C O_{t}^{-}+\sum_{i=1}^{k} \beta_{i} \Delta Y_{t-1}+$ $\sum_{i=1}^{n}\left(\rho_{j}^{+} \Delta B C O_{t-1}^{+}+\rho_{j}^{-} \Delta B C O_{t-1}^{-}\right)+e_{t}$

Where $\Delta$ is the first difference operator, $k$ and $n$ are the lag orders and $e_{t}$ is the white noise error. 
$\rho_{j}^{+}=\omega \theta_{\mathrm{j}}^{+}$and $\rho_{j}^{-}=\omega \theta_{\mathrm{j}}^{-}$

The long-term asymmetric parameters can be measured as $\delta^{+}=\frac{\alpha_{2}^{+}}{\alpha_{1}}$ and $\delta^{-}=\frac{\alpha_{2}^{-}}{\alpha_{1}}$. These parameters represent the long-term effect of oil price increases and decreases on the stock market indices. If the long-term coefficients $\frac{\alpha_{2}^{+}}{\alpha_{1}}$ and $\frac{\alpha_{2}^{-}}{\alpha_{1}}$ are not the equal then there is symmetry in the long-term. The null hypothesis of $\frac{\alpha_{2}^{+}}{\alpha_{1}}=$ $\frac{\alpha_{2}^{-}}{\alpha_{1}}$ is tested and if this hypothesis is rejected then there is an evidence of long-term asymmetry in the model.

\section{Asymmetric Cointegration Test}

Whereas in the ARDL model, the long-term relationship between the variables is established by testing the null hypothesis of no cointegration $\left(\alpha_{1}=\alpha_{2}^{+}\right.$ $\left.=\alpha_{2}^{-}=0\right)$, in the non-linear ARDL model, the long-term $\left(\alpha_{1}=\alpha_{2}^{+}=\alpha_{2}^{-}\right)$and the short-term $\left(\rho_{j}^{+}=\rho_{j}^{-}\right)$ asymmetries are tested using the standard Wald test.

\section{Testing Symmetry}

The asymmetric cumulative dynamic multiplier effect of a unit change in $\mathrm{BCO}^{+}$and $\mathrm{BCO}^{-}$on $Y_{t}$ is investigated as:

$m_{\tau}^{+}=\sum_{i=0}^{\tau} \frac{\sigma Y_{t+1}}{\sigma B C O_{t}^{+}}, m_{\tau}^{-}=\sum_{i=0}^{\tau} \frac{\sigma Y_{t+1}}{\sigma B C O_{t}^{-}}, \tau=0,1,2,$. as $\tau \rightarrow \infty, m_{t}^{+} \rightarrow \alpha_{1}$ and $m_{t}^{-} \rightarrow \alpha_{2}$

\section{EMPIRICAL RESULTS}

\subsection{Descriptive Statistics}

The descriptive statistics of the data samples used in the analysis are provided in Table 2. All data series used in the study exhibited low sample standard deviations which indicates that the percentage changes of these samples are clustered close to the mean. The data series of all the samples evaluated displayed a positive skewness. In terms of Kurtosis, all data samples exhibited a leptokurtic tendency having shown excess kurtosis values $(k>3)$. This indicates all the data set have longer flatter tails and higher sharp central peaks. The Jarque-Bera test for normality showed that the data series for J530, J540, J550 and J560 are normally distributed as their Jarque-Bera values are lower than the critical value of 5.99 at $5 \%$. The rest of the data series (BCO, J203, J510, J520, J580 and J590) however, showed tendency to depart from normal distribution as evident from Jarque-Bera values which were higher that the critical value of 5.99 .

\subsection{Unit Root Analysis}

The first step, before the evaluation of the relationship between the changes in oil price and stock market indices returns was to test for unit root analysis in each data series. The testing procedure requires that no I(2) variables be included in the estimates equation. The unit root tests were conducted using the ADF test at $5 \%$ and the lag length in all the tests were selected according to the Schwarz Information Criterion (SIC). The results of the unit roots tests at levels $[\mathrm{I}(0)]$ and first difference $[\mathrm{I}(1)]$ for all the data sets are shown in Table 3.

The Unit root test results showed that the all the data sets are integrated $\mathrm{I}(0)$ and $\mathrm{I}(1)$ at $1 \%$ and $5 \%$ level. No data series was integrated at I(2). This means that there will be no statistical biases with the data sets therefore the estimation of short-term and long-term can be conducted using NARDL

The data sets for BCO, J203, J510, J520, J560, $\mathrm{J} 580$ and $\mathrm{J} 590$ exhibited neither an intercept nor a trend in their models at both $\mathrm{I}(0)$ and $\mathrm{I}(1)$. This shows that at both $\mathrm{I}(0)$ and $\mathrm{I}(1)$ the data was stationary around the zero value. J530 and J550 exhibited an intercept but no trend in their models at $\mathrm{I}(0)$, however, they exhibited neither an intercept nor a trend at $\mathrm{I}(1)$. The

Table 2: Descriptive Statistics of the Data Sample

\begin{tabular}{|c|c|c|c|c|c|c|c|c|c|c|}
\hline & BCO & J203 & J510 & J520 & J530 & J540 & J550 & J560 & J580 & J590 \\
\hline \hline Mean & 0,003 & $-0,006$ & 0,001 & 0,004 & $-0,013$ & $-0,011$ & $-0,018$ & $-0,001$ & $-0,006$ & $-0,009$ \\
\hline Median & $-0,014$ & $-0,001$ & 0,005 & $-0,003$ & $-0,012$ & 0,015 & $-0,025$ & $-0,001$ & $-0,009$ & $-0,012$ \\
\hline Max & 0,313 & 0,150 & 0,256 & 0,165 & 0,139 & 0,151 & 0,179 & 0,171 & 0,156 & 0,242 \\
\hline Min & 0,184 & $-0,116$ & $-0,167$ & $-0,109$ & $-0,145$ & $-0,125$ & $-0,012$ & $-0,170$ & $-0,116$ & $-0,251$ \\
\hline Std. Dev & 0,093 & 0,044 & 0,075 & 0,045 & 0,052 & 0,051 & 0,054 & 0,063 & 0,046 & 0,067 \\
\hline Skewness & 1,007 & 0,391 & 0,455 & 0,686 & 0,089 & 0,497 & 0,378 & 0,041 & 0,613 & 0,391 \\
\hline Kurtosis & 4,687 & 4,341 & 3,819 & 4,339 & 3,647 & 3,371 & 3,228 & 3,399 & 4,446 & 5,207 \\
\hline Jarque-Bera & 34,240 & 11,949 & 7,443 & 18,237 & 2,232 & 5,584 & 3,090 & 0,825 & 17,831 & 27,174 \\
\hline pbb & 0,000 & 0,003 & 0,024 & 0,000 & 0,316 & 0,302 & 0,213 & 0,662 & 0,000 & 0,000 \\
\hline
\end{tabular}

Notes: BCO denotes Brent Crude Oil, J203 is the JSE AllShare index, J510 is the JSE Basic Materials index, J520 is the JSE Industrials index, J530 is the JSE Consumer Goods index, J540 is the JSE Healthcare index, J550 is the JSE Consumer Services index, J560 is the JSE Telecommunications index, J580 is the JSE Financials index and J590 is the JSE Technology index. 
Table 3: ADF Unit Root Test Results of Brent Crude Oil and JSE Indices at 5\%

\begin{tabular}{|c|c|c|}
\hline Variable & Levels $[I(0)]$ & 1st Difference [I(1)] \\
\hline $\mathrm{BCO}$ & $-6,937^{\star *(\mathrm{c})}$ & $-15,220^{* *(c)}$ \\
\hline J203 & $-11,795^{\star \star(c)}$ & $-11,391^{* *(\mathrm{c})}$ \\
\hline $\mathrm{J} 510$ & $-11,888^{* *(c)}$ & $-10,148^{* *(\mathrm{c})}$ \\
\hline J520 & $-11,972^{* *(c)}$ & $-14,154^{* *(c)}$ \\
\hline $\mathrm{J} 530$ & $-14,170^{\star *(b)}$ & $-10,202^{\star *(c)}$ \\
\hline $\mathrm{J} 540$ & $-10,670^{* \star(a)}$ & $-11,103^{\star *(\mathrm{c})}$ \\
\hline J550 & $-13,886^{* *(b)}$ & $-11,001^{* *(\mathrm{c})}$ \\
\hline J560 & $-12,617^{\star *(\mathrm{c})}$ & $-11,219^{* *(c)}$ \\
\hline J580 & $-11,862^{\star *(c)}$ & $-13,029^{* *(c)}$ \\
\hline $\mathrm{J} 590$ & $-7,073^{\star *(c)}$ & $-12,045^{\star *(\mathrm{c})}$ \\
\hline
\end{tabular}

Notes: * and ${ }^{* *}$ denotes rejection of the Null hypothesis at $5 \%$ and $1 \%$ level respectively, ${ }^{(a)}$ represent models with intercept and trend, ${ }^{(b)}$ represents models with intercept only and ${ }^{(\mathrm{c})}$ represents models without intercept nor trend.

results observed at $\mathrm{I}(0)$ indicate that the data was stationary at a constant value that is not equal to zero.

$\mathrm{J} 540$ data exhibited an intercept and a trend at $\mathrm{I}(0)$ but neither an intercept nor a trend was observed at $\mathrm{I}(1)$. The results obtained at $\mathrm{I}(0)$ indicate that the data was stationary at a value that is not equal to zero and there is a no tendency to follow a trend.

\subsection{Cointegration Test}

The cointegration test estimate Equation 2 using appropriate lag order. Critical values of Case I of Pesaran (2001) were used in our analysis at $\mathrm{I}(1)$ for BCO, J203, J510, J520, J560, J580 and J590, the reason being that all the data sets exhibited a model with no intercept and no trend at the I(1). For data sets of J530 and J550 Case II critical values of Pesaran (2001) were used because the data sets exhibited a model with restricted intercept but no trend. The cointegration test results are summarised in Table 4. A strong presence of cointegration was observed between oil price and the majority of JSE indices which showed cointegration even at $1 \%$ level irrespective of the model that the dataset exhibited, as result that is contrary to Abdelaziz, Chortareas, and Cipollini (2008) who reported no cointegration between oil price and stock prices.

However, J510 index returns did not show cointegration with oil price changes due to $\mathrm{F}$ - statistic which was lower than the critical value of Case II hence

Table 4: Bounds Tests Results for Non-Linear Cointegration at $1 \%, 5 \%$ and $10 \%$ Level of Confidence

\begin{tabular}{|c|c|c|}
\hline Variable & F-Statistic & Conclusion \\
\hline \hline $\mathrm{J} 510$ & 1,097 & No cointegration \\
\hline $\mathrm{J} 520$ & $46,784^{\star * *}$ & Cointegration \\
\hline $\mathrm{J} 530$ & $46,226^{\star * *}$ & Cointegration \\
\hline $\mathrm{J} 540$ & $39,636^{\star \star *}$ & Cointegration \\
\hline $\mathrm{J} 550$ & $48,908^{\star * *}$ & Cointegration \\
\hline $\mathrm{J} 560$ & $55,863^{\star * *}$ & Cointegration \\
\hline $\mathrm{J} 580$ & $50,952^{\star \star *}$ & Cointegration \\
\hline $\mathrm{J} 590$ & $59,912^{\star * *}$ & \\
\hline
\end{tabular}

\begin{tabular}{|c|c|c|c|}
\hline Significance & Case I Critical values for I(1) & Case II Critical values for I(1) & Case III Critical values for I(1) \\
\hline \hline $10 \%$ level & 3.28 & 3.51 & 4.78 \\
\hline $5 \%$ level & 4.11 & 4.16 & 5.73 \\
\hline $1 \%$ level & 6.02 & 5.58 & 7.84 \\
\hline
\end{tabular}

Notes: The bounds test critical values are based on Case I and Case II of M. Hashem Pesaran, Yongcheol Shin, and Richard J. Smith (2001). * denotes significance at $10 \%$ level, ${ }^{* *}$ denotes significance at $5 \%$ level and ${ }^{* *}$ denotes significance at $1 \%$ level. 
the we failed to reject the null hypothesis that the is no cointegration between the variables and could not be analysed further. Similar result was reported for the Kuwait Stock Market were Basic Materials did not show cointegration with Brent Crude Oil (Kisswani \& Elian, 2017). It can be concluded that there is long-term effect on stock market prices from oil price changes on all indices, except for Basic Materials index (J510). This finding which show a predominantly homogeneous long-term effect of oil price changes on stock market indices is contrary to that of Kisswani and Elian (2017) who reported a heterogeneous long-term effect of oil price changes on stock market indices. This was attributed the nature of the two countries used in the studies, i.e. an oil-importing country (South Africa) versus an oil-exporting country (Kuwait) which Kisswani and Elian (2017) studied.

\subsection{Residual Diagnostics Tests}

Before analysing the model to determine the long-term coefficients and the symmetry in the long-term and short-term, it is important to evaluate the adequacy of the dynamic specifications based on a number of diagnostic tests. The following diagnostics tests were conducted; the stability test was conducted using the Ramsey test, the Jarque-Bera statistic was used to test for the error normality test and the ARCH statistic was used to test for heteroskedasticity and the results are provided in Table 5 .

The RAMSEY'S RESET test is designed to test for any mis-specification in the model. This is done by testing if the linear regression is mis-specified. The RAMSEY test therefore tests the null hypothesis that the value of $Y$ is zero. The results shown in Table $\mathbf{5}$ indicate that the $p$-values of all the models specified are greater than 0.05 hence the null hypothesis could not be rejected. This indicated that there was no sign of mis-specification in the models.
The Jarque-Bera result is used as a test for normality of the data. Models usually assume that the data be used in the model is from a normally distributed sample. The Jarque-Bera is designed to test the null hypothesis that the sample is from a normal distribution. Based on the results shown in Table 5, the null hypothesis cannot be rejected. Overall the result indicated that the model passed the normality test.

The ARCH tests results as shown in Table $\mathbf{5}$ show that the $p$-values were all greater than 0,05 hence the null hypothesis could not be rejected. This indicated that there was no $\mathrm{ARCH}$ effect in the model. Overall, based on these tests, the models passed the diagnostics tests conducted.

\subsection{Non-Linear ARDL Estimation}

The JSE stock market indices that were found to be cointegrated with oil price were analysed to determine the cointegration values, i.e. the short-term and long-term coefficients. Therefore J510 was not evaluated because no cointegration was observed between the index and oil price data. The diagnostics tests also provided sufficient positive results to continue with analysis as they indicate adequate specifications since the models pass the normality test, and was free of any autocorrelation.

\subsubsection{Long-Term Coefficients}

The long-term $L_{B C O}^{+}$and $L_{B C O}^{-}$coefficients were calculated by the following equations $L_{B C O}^{+}=$ $\frac{-B C O_{-} P(-1)}{S(-1)}$ and $L_{B C O}^{-}=\frac{-B C O_{-} N(-1)}{S(-1)}$ where $\mathrm{S}(-1)$ represents the coefficients of the stock index e.g. J510 $(-1)$. The results of the long-term coefficients of the oil price and the various stock market indices are shown in Table 6.

The positive and negative long-term coefficients were both positive for the J520, J550 and J590. The result suggest a response to oil price changes where

Table 5: Diagnostics Test Results of the Different Models

\begin{tabular}{|c|c|c|c|}
\hline & RAMSEY'S RESET & $\chi_{J B}^{2}$ & $\chi_{A R C H}^{2}$ \\
\hline J510 & $-0.585(0.598)$ & $0.224(0.894)$ & $0.411(0.522)$ \\
\hline J520 & $1.385(0.181)$ & $1.488(0.475)$ & $0.0404(0.841)$ \\
\hline J530 & $-0.294(0.653)$ & $0.112(0.945)$ & $1.933(0.164)$ \\
\hline J540 & $-0.628(0.479)$ & $0.725(0.696)$ & $0.477(0.490)$ \\
\hline J550 & $-1.195(0.116)$ & $1.853(0.396)$ & $2.947(0.086)$ \\
\hline $\mathrm{J} 560$ & $0.258(0.582)$ & $0.715(0.699)$ & $0.0984(0.754)$ \\
\hline J580 & $-0.0847(0.887)$ & $0.0259(0.987)$ & $1.476(0.224)$ \\
\hline J590 & $-0.177(0.737)$ & $1.748(0.417)$ & 0.3080 .578 \\
\hline
\end{tabular}

RAMSEY's RESET is the result of the stability tests, $\chi_{J B}^{2}$ indicates the results of the Jargue-Bera normality test and $\chi_{A R C H}^{2}$ indicates results of the heteroskedasticity test. 
Table 6: The Long-Term Coefficients of Oil Price Changes on the JSE Stock Market Indices Returns

\begin{tabular}{|c|c|c|}
\hline Index & $\mathbf{L}_{\text {BCo }}^{+}$ & $\mathbf{L}_{\text {BCo }}^{-}$ \\
\hline \hline$J 520$ & 0,058 & $-0,041$ \\
\hline$J 530$ & $-0,050$ & $-0,052$ \\
\hline$J 540$ & 0,001 & 0,045 \\
\hline$J 550$ & 0,048 & 0,002 \\
\hline$J 560$ & $-0,017$ & $-0,017$ \\
\hline$J 580$ & $-0,001$ & 0,064 \\
\hline
\end{tabular}

the positive change in the oil price resulted in an increase in the index price and negative change in oil price resulted in a decrease in the index price in the long-term. When evaluating J520 and J550 it was found that in the long-term the impact of oil price changes were of low magnitude where a $10 \%$ increase in oil price caused a $0.6 \%, 0.4 \%$ and $0.7 \%$ increase for J520, J550 and J590, respectively. This behaviour was also observed when considering decrease in oil prices. J520, J550 and J590 responded more positively to decrease in oil prices compared to oil price increases. The positive and negative long-term coefficients for $\mathrm{J} 530$ and $\mathrm{J} 580$ were both negative and low in magnitude characterised by a stronger response to oil price decrease compared to oil price increases. The result suggest a response behaviour whereby the positive change in the oil price would result in a decrease in the index price and a negative change in oil price will result in a positive change in index price in the long-term. The result for J540 indicated that both positive and negative changes in the oil price resulted in positive change in the index price and was also characterised by low magnitude coefficients as a $10 \%$ increase or decrease would result in $0.01 \%$ and $0.02 \%$ change respectively. However, J560 showed a behaviour that is contrary to J540 in that the results indicate that both a positive and negative change in oil price resulted in a negative change in the index price but the magnitude of the coefficients remained significantly low as a $10 \%$ increase or decrease in oil prices would only cause a $0.2 \%$ and $0.02 \%$ change in stock price change respectively.

At a higher level, it appears all indices studied where characterised by significantly low magnitude of long term coefficients indicating that the JSE Industrial stock indices are relatively neutral to the oil price changes in the long-term. However, a detailed analysis reveal that JSE Industrial stock indices respond to oil price changes in a heterogeneous manner since direction of long-term impact of oil price changes vary with sector, a finding that is supported by other researchers (Arouri \& Nguyen, 2010; Broadstock \& Filis, 2014; Malik \& Ewing, 2009). Prices changes of
Industrials (J520), Consumer services (J550) and Technology (J590) were found to follow the direction of the oil price changes whereas those of Consumer goods (J530) and Financials (J580) opposed the direction of the oil price changes. Healthcare (J540) and Telecommunications (J560) appeared to be influenced by secondary changes as both positive and negative changes led to unidirectional changes for these indices, i.e. positive change and negative change for J540 and J560, respectively. The main characteristic between these two indices is their relatively small market capitalisation size (Healthcare 6809 and Telecommunications - 5633 (Sharenet, 2018))

\subsubsection{Test for Long-Term and Short-Term Symmetry}

The empirical analysis involves the selection of the best fitting NARDL specifications. This was achieved by estimating the symmetric and asymmetric impact of oil price changes to the stock market prices changes using Equation 2 and 6 . The null hypothesis of the symmetry in the long-term versus the asymmetry was tested using the Wald statistic where the null hypothesis of $\frac{\alpha_{2}^{+}}{\alpha_{1}}=\frac{\alpha_{2}^{-}}{\alpha_{1}}$ was tested and if this hypothesis can be rejected then there is an evidence of long-term asymmetry in the model. For short-term symmetry the null hypothesis of symmetry was tested against asymmetry. The Wald test procedure for the test consists of statistic with the null $\sum_{n=1}^{n} \rho_{i}^{+}=$ $\sum_{n=1}^{n} \rho_{i}^{-}$. The results of the short-term and long-term symmetry obtained from the Wald test are shown in Table 7. The test did not include J510 because no cointegration was found between oil price data and this Index. Based on the results provided in Table 7, it was found that in all the indices evaluated, the null hypothesis of short-term symmetry can be rejected even at $1 \%$ level indicating the presence of short-term asymmetric impact of oil price changes on the industrial stock prices. For the long-term symmetry, however, the null hypothesis could not be rejected for all the variable pairs evaluated. This result suggests that there is long-term asymmetric impact of oil price changes on stock market indices were statistically insignificant for the JSE industry stock indices during the period studied. 
Table 7: Short-Term and Long-Term Symmetry Test Results

\begin{tabular}{|c|c|c|}
\hline & $W_{S R, B C o}$ & $W_{L R, B C O}$ \\
\hline J520 & $\begin{array}{c}46,784^{\star *} \\
(0.000)\end{array}$ & $\begin{array}{c}2.136 \\
(0.148)\end{array}$ \\
\hline J530 & $\begin{array}{c}46.226^{* *} \\
(0.000)\end{array}$ & $\begin{array}{l}0.0307 \\
(0.861)\end{array}$ \\
\hline $\mathrm{J} 540$ & $\begin{array}{c}39.636^{\star *} \\
(0.000)\end{array}$ & $\begin{array}{c}1.655 \\
(0.201)\end{array}$ \\
\hline J550 & $\begin{array}{c}48.908^{\star *} \\
(0.000)\end{array}$ & $\begin{array}{l}0.0492 \\
(0.825)\end{array}$ \\
\hline J560 & $\begin{array}{c}55.863^{\star *} \\
(0.000)\end{array}$ & $\begin{array}{l}0.0011 \\
(0.974)\end{array}$ \\
\hline J580 & $\begin{array}{c}50.952^{* *} \\
(0.000)\end{array}$ & $\begin{array}{l}2.937 \\
(0.09)\end{array}$ \\
\hline J590 & $\begin{array}{c}59.912^{* *} \\
(0.000)\end{array}$ & $\begin{array}{l}0.0297 \\
(0.867)\end{array}$ \\
\hline
\end{tabular}

Notes: $\mathrm{W}_{\mathrm{SR}, \mathrm{BCO}}$ denotes the Wald test for the short-term symmetry which tests the null hypothesis $\rho_{j}^{+}=\rho_{j}^{-}$and $\mathrm{W}_{\mathrm{LR}, \mathrm{BCO}}$ denotes the Wald test for the short-term symmetry which tests the null hypothesis $\alpha_{2}^{+}=\alpha_{2}^{-}$in Equation 6 . The associated p-values are provided in brackets below the value. * and ${ }^{* *}$ indicates rejection of the null hypothesis of the short-term and long-term symmetry at $5 \%$ and $1 \%$ level respectively.

Table 8: The Nonlinear ARDL Estimation Results of JSE Stock Indices Against Brent Crude Oil Prices

\begin{tabular}{|c|c|c|c|c|c|c|c|}
\hline \multirow{2}{*}{$\begin{array}{l}\text { Independent } \\
\text { variable }\end{array}$} & J520 & J530 & J540 & J550 & J560 & J580 & J590 \\
\hline & $\begin{array}{l}\text { NARDL with } \\
\text { SR asymmetry }\end{array}$ & $\begin{array}{l}\text { NARDL with } \\
\text { SR asymmetry }\end{array}$ & $\begin{array}{l}\text { NARDL with } \\
\text { SR asymmetry }\end{array}$ & $\begin{array}{l}\text { NARDL with } \\
\text { SR asymmetry }\end{array}$ & $\begin{array}{c}\text { NARDL with } S R \\
\text { asymmetry }\end{array}$ & $\begin{array}{l}\text { NARDL with } \\
\text { SR asymmetry }\end{array}$ & $\begin{array}{c}\text { NARDL with SR } \\
\text { asymmetry }\end{array}$ \\
\hline $\mathrm{C}$ & $0.054(0.003)$ & $0.029(0.178)$ & $-0.0009(0.964)$ & $0.027(0.122)$ & $-0.020(0.464)$ & $0.045(0.006)$ & $-0.088(0.005)$ \\
\hline$S(-1)$ & $-1.051(0.000)$ & $-1.143(0.000)$ & $-0.979(0.000)$ & $-1.130(0.000)$ & $-1.560(0.000)$ & $-1.120(0.000)$ & $-1.127(0.000)$ \\
\hline BCO_P(-1) & $0.061(0.115)$ & $-0.057(0.201)$ & $0.0007(0.988)$ & $0.054(0.233)$ & $-0.028(0.701)$ & $-0.002(0.961)$ & $0.076(0.272)$ \\
\hline BCO_N(-1) & $0.043(0.231)$ & $-0.060(0.146)$ & $-0.020(0.663)$ & $0.051(0.243)$ & $0.003(0.960)$ & $-0.019(0.503)$ & $0.073(0.246)$ \\
\hline \multicolumn{8}{|l|}{$\triangle B C O \_P$} \\
\hline \multicolumn{8}{|l|}{$\triangle \mathrm{BCO} \_\mathrm{N}$} \\
\hline$\Delta \mathrm{S}(-1)$ & & & & & $0.315(0.000)$ & & \\
\hline$\Delta \mathrm{S}(-3)$ & $0.130(0.012)$ & & & & & & \\
\hline$\Delta S(-4)$ & & & & & & & $0.220(0.004)$ \\
\hline$\Delta S(-5)$ & & & & & & & $0.232(0.017)$ \\
\hline$\Delta S(-6)$ & & & & & $0.072(0.127)$ & & $0.305(0.002)$ \\
\hline$\Delta \mathrm{S}(-7)$ & & & & & & & $0.189(0.012)$ \\
\hline$\Delta S(-8)$ & & & & & & $0.146(0.001)$ & \\
\hline$\Delta \mathrm{S}(-9)$ & $0.149(0.001)$ & & & & & $0.220(0.000)$ & \\
\hline$\triangle B C O \_P(-1)$ & & & & & $0.316(0.004)$ & & \\
\hline$\triangle B C O \_N(-1)$ & $-0.080(0.052)$ & & & & & & \\
\hline$\triangle \mathrm{BCO} \_\mathrm{N}(-2)$ & & & & & $0.278(0.0009)$ & & \\
\hline$\triangle B C O \_P(-3)$ & $-0.121(0.021)$ & & & & $0.233(0.018)$ & & \\
\hline$\triangle B C O \_N(-3)$ & & $0.140(0.003)$ & & & & & \\
\hline$\triangle B C O \_P(-4)$ & & & & & $0.258(0.009)$ & & \\
\hline$\triangle B C O \_N(-4)$ & & & & & $0.162(0.033)$ & & \\
\hline$\triangle B C O \_P(-5)$ & & $0.192(0.004)$ & & & $0.321(0.0007)$ & & \\
\hline$\triangle B C O \_P(-6)$ & & & & & & & $0.292(0.0008)$ \\
\hline$\triangle \mathrm{BCO} \_\mathrm{N}(-6)$ & & $0.096(0.050)$ & & & & & \\
\hline$\triangle \mathrm{BCO} \_\mathrm{P}(-7)$ & $-0.119(0.013)$ & & & & & & \\
\hline$\triangle B C O \_N(-7)$ & & $0.109(0.023)$ & $-0.135(0.006)$ & & & & \\
\hline
\end{tabular}


(Table 8). continued

\begin{tabular}{|c|c|c|c|c|c|c|c|}
\hline \multirow{2}{*}{$\begin{array}{l}\text { Independent } \\
\text { variable }\end{array}$} & J520 & J530 & J540 & J550 & J560 & J580 & J590 \\
\hline & $\begin{array}{l}\text { NARDL with } \\
\text { SR asymmetry }\end{array}$ & $\begin{array}{l}\text { NARDL with } \\
\text { SR asymmetry }\end{array}$ & $\begin{array}{l}\text { NARDL with } \\
\text { SR asymmetry }\end{array}$ & $\begin{array}{l}\text { NARDL with } \\
\text { SR asymmetry }\end{array}$ & $\begin{array}{c}\text { NARDL with SR } \\
\text { asymmetry }\end{array}$ & $\begin{array}{l}\text { NARDL with } \\
\text { SR asymmetry }\end{array}$ & $\begin{array}{c}\text { NARDL with } S R \\
\text { asymmetry }\end{array}$ \\
\hline$\triangle \mathrm{BCO} \_\mathrm{P}(-8)$ & & $0.135(0.049)$ & & & $0.314(0.001)$ & & \\
\hline$\triangle B C O \_N(-8)$ & & & & & $-0.322(0.000)$ & & \\
\hline$\triangle B C O \_N(-9)$ & & $0.131(0.009)$ & & & & & \\
\hline$\triangle \mathrm{BCO} \_\mathrm{N}(-10)$ & & & & & & $-0.086(0.008)$ & $0.226(0.019)$ \\
\hline$\triangle B C O \_N(-11)$ & & & & & & & $-0.173(0.014)$ \\
\hline$\triangle \mathrm{BCO} \_\mathrm{P}(-12)$ & $-0.119(0.017)$ & $0.129(0.042)$ & & & & $-0.117(0.005)$ & $-0.221(0.023)$ \\
\hline$\triangle \mathrm{BCO} \_\mathrm{N}(-12)$ & & $-0.202(0.014)$ & $-0.114(0.028)$ & & & & $0.214(0.006)$ \\
\hline
\end{tabular}

\subsubsection{Short-Term Coefficients}

To determine the short-term coefficients, the partial sums of the negative and positive changes $\triangle B C O$ (BCO_p and BCO_n) were evaluated. Table 8 show the results of the short-term coefficients. The coefficients of partial sums of positive and negative were not statistically significant at $5 \%$ confidence.

\section{CONCLUSION}

Econometric models have been employed to study the impact of oil price changes on various economic variables. Predominantly, these models have been linear in nature thus leading to a number of limitations such as providing one dimensional analysis. The development of the non-linear models, especially the NARDL, brought the agility required to simultaneously evaluate both the long-term and short-term dynamics of the relationship and the symmetrical nature of the impact. Using the NARDL, this study analysed the impact of oil price changes on JSE stock market indices at an aggregated industrial index level and found that the impact of oil price on the different stock market indices of the JSE were of varying dimension and magnitude especially in the long term. The long-term coefficient results, however, showed relatively low magnitude long-term coefficients indicating that the impact of oil price did not have a significant long-term effect on the indices. However, the indices responded in heterogeneous manner indicating that oil prices changes had varied impact on the indices. The Wald test showed that the null hypothesis for short-term symmetry in can be rejected even at $1 \%$ confidence but the null hypothesis for long-term symmetry could not be rejected with only $\mathrm{J} 580$ that can be rejected at $10 \%$ confidence. It was therefore concluded that there was short-term asymmetry and long-term symmetry in the price changes of JSE industrial indices in response to oil price changes. The residual diagnostics showed that the model passed the normality test and was free of autocorrelation hence it was a robust model. The result indicate that investors need to consider the short-term asymmetric impact of oil prices on stock market prices when making investment decisions and incorporate the non-linear impact of oil price changes on stock markets. For further study, it is recommended to consider lower level data in order to reduce the impact of aggregation used in market capitalisation so as to unpack the impact of oil prices changes on homogeneous sectors. For example, using level index data would enable to understand the Banking sector and the Insurance are impacted by changes in oil prices. Industry level data is highly consolidated may contain diverse sectors whose response to changes in oil price changes may differ and counteract each other. Furthermore, due to capitalisation mechanisms, the dominant sector in an Industrial index may influence the results thus yielding a result that is not a true reflection of the industrial index composition.

\section{REFERENCES}

Abdelaziz Mohamed, Chortareas Georgios, and Cipollini Andrea. (2008). Stock Prices, Exchange Rates, and Oil: Evidences from Middle East Oil-exporting Countries. Topics in Middle Eastern and North African Economies, Electronic Journal, 10 1-28. http://www.luc.edu/orgs/meea

Adebiyi M Adebayo, Adenuga A Oluwaseun, and Omanukwue N Phebian. (2009). Oil Price Shocks, Exchange Rate and Stock Market Behaviour: Empirical Evidence from Nigeria. Paper presented at the Proceedings of the 14th Annual Conference of the African Econometric Society.

Adetunji Babatunde, Musibau A Olayinka, and Adenikinju F Adeola. (2013). Oil Price Shocks and Stock Market Behaviour in Nigeria. Journal of Economic Studies, 40(2), 180-202. https://doi.org/10.1108/01443581311283664

Aleisa Eisa, \& Dibooglu Sel. (2004). Relationships Among US Oil Prices and Oil Industry Equity Indices. International Review of Economics and Finance, 13(4), 427-453. https://doi.org/10.1016/S1059-0560(03)00011-X

Aloui Chaker, and Jammazi Rania. (2009). The Effects of Crude Oil Shocks on Stock Market Shifts Behaviour: A Regime Switching Approach. Energy Economics, 31(5), 789-799. https://doi.org/10.1016/j.eneco.2009.03.009

An Haizhong, Gao Xiangyun, Fang Wei, Huang Xuan, and Ding Yinghui. (2014). The Role of Fluctuating Modes of Autocorrelation in Crude Oil Prices. Physica A: Statistical Mechanics and its Applications, 393, 382-390. https://doi.org/10.1016/j.physa.2013.08.055

Arouri Mohamed El Hedi and Nguyen Duc Khuong. (2010). Oil Prices, Stock Markets and Portfolio Investment: Evidence from Sector Analysis in Europe over the Last Decade. Energy Policy, 38(8), 4528-4539. https://doi.org/10.1016/j.enpol.2010.04.007 
Arouri Mohamed El Hedi, and Rault Christophe. (2012). Oil Prices and Stock Markets in GCC Countries: Empirical Evidence from Panel Analysis. International Journal of Finance and Economics, 17(3), 242-253. https://doi.org/10.1002/ijfe.443

Asteriou Dimitrios and Bashmakova Yuliya. (2013). Assessing the Impact of Oil Returns on Emerging Stock Markets: A Panel Data Approach for Ten Central and Eastern European Countries. Energy Economics, 38, 204-211. https://doi.org/10.1016/j.eneco.2013.02.011

Bachmeier Lance. (2008). Monetary policy and the transmission of oil shocks. Journal of Macroeconomics, 30(4), 1738-1755. https://doi.org/10.1016/j.jmacro.2007.11.002

Balcilar Mehmet, van Eyden Reneé, Uwilingiye Josine, and Gupta Rangan. (2017). The Impact of Oil Price on South African GDP Growth: A Bayesian Markov Switching-VAR Analysis. African Development Review, 29(2), 319-336. https://doi.org/10.1111/1467-8268.12259

Basher Syed A, and Sadorsky Perry. (2006). Oil Price Risk and Emerging Stock Markets. Global Finance Journal, 17(2), 224-251.

https://doi.org/10.1016/j.gfj.2006.04.001

Batac, V Charday, And Tatlonghari M Virgilio. (2013). The Behavior of Exchange Rates, Crude Oil Prices, and Money Supply and Their Effects on Philippines Stock Market Performance: A Cointegration Analysis. Review of Integrative Business and Economics Research, 2(2), 60-168.

Beckmann Joscha, Czudaj Robert, and Arora Vipin. (2017). The Relationship between Oil Prices and Exchange Rates: Theory and Evidence. Washington DC US Energy Information Administration Working paper series

Boyer M Martin, and Filion Didier. (2007). Common and Fundamental Factors in Stock Returns of Canadian Oil and Gas Companies. Energy Economics, 29(3), 428-453. https://doi.org/10.1016/j.eneco.2005.12.003

Breeden T Douglas. (2005). An Intertemporal Asset Pricing Model with Stochastic Consumption and Investment Opportunities Theory Of Valuation (pp. 53-96): World Scientific Publishing Company.

https://doi.org/10.1142/9789812701022_0003

Broadstock C David, and Filis George. (2014). Oil Price Shocks and Stock Market Returns: New Evidence from the United States and China. Journal of International Financial Markets, Institutions and Money, 33, 417-433. https://doi.org/10.1016/j.intfin.2014.09.007

Brown P A Stephen, and Yücel K Mine. (2002). Energy Prices and Aggregate Economic Activity: an Interpretative Survey. The Quarterly Review of Economics and Finance, 42(2), 193-208. https://doi.org/10.1016/S1062-9769(02)00138-2

Burbidge John, and Harrison Alan. (1984). Testing for the Effects of Oil-price Rises using Vector Autoregressions. International Economic Review, 459-484. https://doi.org/10.2307/2526209

Chen Shiu-Sheng. (2009). Predicting the Bear Stock Market: Macroeconomic Variables as Leading Indicators. Journal of Banking \& Finance, 33(2), 211-223. https://doi.org/10.1016/j.jbankfin.2008.07.013

Chinzara Zivanemoyo. (2011). Macroeconomic Uncertainty and Conditional Stock Market Volatility in South Africa. South African Journal of Economics, 79(1), 27-49. https://doi.org/10.1111/j.1813-6982.2011.01262.x

Chisadza Carolyn, Dlamini Janneke, Gupta Rangan, and Modise P Mampho. (2016). The Impact of Oil Shocks on the South African Economy. Energy Sources, Part B: Economics, Planning, and Policy, 11(8), 739-745. https://doi.org/10.1080/15567249.2013.781248

Chou Kuo-Wei, and Tseng Yi-Heng. (2016). Oil Prices, Exchange Rate, and the Price Asymmetry in the Taiwanese Retail Gasoline Market. Economic Modelling, 52(Part B), 733-741. https://doi.org/10.1016/j.econmod.2015.10.012

Cifarelli Giulio, and Paladino Giovanna. (2010). Oil Price Dynamics and Speculation: A Multivariate Financial Approach. Energy Economics, 32(2), 363-372. https://doi.org/10.1016/j.eneco.2009.08.014
Ciner Cetin. (2001). Energy Shocks and Financial Markets: Nonlinear Linkages. Studies in Nonlinear Dynamics \& Econometrics, 5(3).

https://doi.org/10.2202/1558-3708.1079

Ciner Cetin. (2013). Oil and Stock Returns: Frequency Domain Evidence. Journal of International Financial Markets, Institutions and Money, 23, 1-11.

https://doi.org/10.1016/j.intfin.2012.09.002

Cochrane John H. (1991). Production-based Asset Pricing and the Link between Stock Returns and Economic Fluctuations. The Journal of Finance, 46(1), 209-237. https://doi.org/10.1111/j.1540-6261.1991.tb03750.x

Cologni Alessandro, and Manera, Matteo. (2008). Oil Prices, Inflation and Interest Rates in a Structural Cointegrated VAR Model for the G-7 Countries. Energy Economics, 30(3), 856-888. https://doi.org/10.1016/j.eneco.2006.11.001

Cong Rong-Gang, Wei Yi-Ming, Jiao Jian-Lin, and Fan Ying. (2008). Relationships between Oil Price Shocks and Stock Market: An Empirical Analysis from China. Energy Policy, 36(9), 3544-3553. https://doi.org/10.1016/j.enpol.2008.06.006

Creti Anna, Ftiti Zied, and Guesmi Khaled. (2014). Oil Price and Financial Markets: Multivariate Dynamic Frequency Analysis. Energy policy, 73, 245-258. https://doi.org/10.1016/j.enpol.2014.05.057

Cunado Juncal, and De Gracia F Perez. (2005). Oil Prices, Economic Activity and Inflation: Evidence for Some Asian Countries. The Quarterly Review of Economics and Finance, 45(1), 65-83.

https://doi.org/10.1016/j.qref.2004.02.003

Cuñado Juncal, and de Gracia F Pérez. (2003). Do Oil Price Shocks Matter? Evidence for Some European Countries. Energy Economics, 25(2), 137-154. https://doi.org/10.1016/S0140-9883(02)00099-3

Dayanandan Ajit, and Donker Han. (2011). Oil Prices and Accounting Profits of Oil and Gas Companies. International Review of Financial Analysis, 20(5), 252-257. https://doi.org/10.1016/j.irfa.2011.05.004

Degiannakis Stavros, Filis George, and Arora Vipin. (2017). Oil Prices and Stock Markets: A Review of the Theory and Empirical Evidence Energy Journal, 39(5), 85-130. https://doi.org/10.5547/01956574.39.5.sdeg

Driesprong Gerben, Jacobsen Ben, and Maat Benjamin. (2008). Striking Oil: Another Puzzle? Journal of Financial Economics, 89(2), 307-327. https://doi.org/10.1016/j.jfineco.2007.07.008

Du Limin, Yanan He, and Wei Chu. (2010). The Relationship between Oil Price Shocks and China's Macro-economy: An Empirical Analysis. Energy policy, 38(8), 4142-4151. https://doi.org/10.1016/j.enpol.2010.03.042

Duma Nombulelo. (2008). Pass-through of External Shocks to Inflation in Sri Lanka. In Charles F Kramer (Ed.), IMF Working Paper (Vol. 08/78): International Monetary Fund. https://doi.org/10.5089/9781451869392.001

El-Sharif Idris, Brown Dick, Burton Bruce, Nixon Bill, and Russell Alex. (2005). Evidence on the Nature and Extent of the Relationship between Oil Prices and Equity Values in the UK. Energy Economics, 27(6), 819-830. https://doi.org/10.1016/j.eneco.2005.09.002

Fama, Eugene. (1965). The Behaviour of Stock Market Prices. The Journal of Business, 38(1), 34-105. https://doi.org/10.1086/294743

Filis George. (2010). Macro Economy, Stock Market and Oil Prices: Do Meaningful Relationships Exist Among their Cyclical Fluctuations? Energy Economics, 32(4), 877-886. https://doi.org/10.1016/j.eneco.2010.03.010

Filis George, and Chatziantoniou Loannis. (2014). Financial and Monetary Policy Responses to Oil Price Shocks: Evidence from Oil-importing and Oil-exporting Countries. Review of Quantitative Finance and Accounting, 42(4), 709-729. https://doi.org/10.1007/s11156-013-0359-7

Ghouri S Saif. (2006). Assessment of the Relationship between Oil Prices and US Oil Stocks. Energy Policy, 34(17), 3327-3333. https://doi.org/10.1016/j.enpol.2005.07.007 
Gjerde Øystein, and Saettem Frode. (1999). Causal Relations among Stock returns and Macroeconomic Variables in a Small, Open Economy. Journal of International Financial Markets, Institutions and Money, 9(1), 61-74. https://doi.org/10.1016/S1042-4431(98)00036-5

Hamilton D James. (1983). Oil and the Macroeconomy since World War II. Journal of Political Economy, 91(2), 228-248. https://doi.org/10.1086/261140

Hamilton D James, and Herrera A Maria. (2004). Oil Shocks and Aggregate Macroeconomic Behavior: the Role of Monetary Policy: a Comment. Journal of Money, Credit, and Banking, 36(2), 265-286. https://doi.org/10.1353/mcb.2004.0012

Henriques Irene, and Sadorsky Perry. (2008). Oil Prices and the Stock Prices of Alternative Energy Companies. Energy Economics, 30(3), 998-1010. https://doi.org/10.1016/j.eneco.2007.11.001

Hooker A Mark. (1996). What Happened to the Oil Price-Macroeconomy Relationship? Journal of monetary Economics, 38(2), 195-213 https://doi.org/10.1016/S0304-3932(96)01281-0

Huang D Roger, Masulis W Ronald, and Stoll R Hans. (1996). Energy Shocks and Financial Markets. Journal of Futures, Options and Other Derivative Products, 16(1), 1-27. https://doi.org/10.1002/(SICl)1096-9934(199602)16:1<1::Al D-FUT1>3.0.CO;2-Q

Huang Xuan, An Haizhong, Gao Xiangyun, Hao Xiaoqing, and Liu Pengpeng. (2015). Multiresolution Transmission of the Correlation Modes between Bivariate Time Series Based on Complex Network Theory. Physica A: Statistical Mechanics and Its Applications, 428, 493-506. https://doi.org/10.1016/j.physa.2015.02.028

Hussin M Y Mohd, Muhammad F Hussin, and Razak, A Abdul. (2012). The Relationship between Oil Price, Exchange Rate and Islamic Stock Market in Malaysia. Research Journal of Finance and Accounting, 3(5), 83-92.

Iheanacho Eugene. (2016). Dynamic Relationship between Crude Oil Price, Exchange Rate and Stock Market Performance in Nigeria. African Research Review, 10(4), 224-240. https://doi.org/10.4314/afrrev.v10i4.16

Jones M Charles, and Kaul Gautam. (1996). Oil and the Stock Markets. The Journal of Finance, 51(2), 463-491. https://doi.org/10.1111/j.1540-6261.1996.tb02691.x

Kisswani M Khalid, \& Elian I Mohammad. (2017). Exploring the Nexus between Oil Prices and Sectoral Stock Prices: Nonlinear Evidence from Kuwait Stock Exchange. Cogent Economics \& Finance, 5(1), 1286061 https://doi.org/10.1080/23322039.2017.1286061

Lacheheb Miloud, and Sirag Abdalla. Oil Price and Inflation in Algeria: A Nonlinear ARDL Approach. Topics in Middle Eastern and African Economies, 18(2), 45-60.

Lanza Alessandro, Manera Matteo, Grasso Margherita, and Giovannini Massimo. (2005). Long-run Models of Oil Stock Prices. Environmental Modelling \& Software, 20(11), 1423-1430.

https://doi.org/10.1016/j.envsoft.2004.09.022

Laopodis T Nikiforos. (2011). Equity Prices and Macroeconomic Fundamentals: International Evidence. Journal of International Financial Markets, Institutions and Money, 21(2), 247-276. https://doi.org/10.1016/j.intfin.2010.10.006

Lardic Sandrine, and Mignon Valerie. (2008). Oil Prices and Economic Activity: An Asymmetric Cointegration Approach. Energy Economics, 30(3), 847-855. https://doi.org/10.1016/j.eneco.2006.10.010

Larsson Rasmus, and Haq Sebastian. (2016). The Dynamics of Stock Market Returns and Macroeconomic Indicators: An ARDL Approach with Cointegration. (MSc Engineering), KTH, Stockholm.

Lawal I Adedoyin, Somoye OC Russel, and Babajide A Abiola. (2016). Impact of Oil Price Shocks and Exchange Rate Volatility on Stock Market Behavior in Nigeria. Binus Business Review, 7(2), 171-177. https://doi.org/10.21512/bbr.v7i2.1453
Lee B Rhae, Lee Kiseok, and Ratti A Ronald. (2001). Monetary Policy, Oil Price Shocks, and the Japanese Economy. Japan and the World Economy, 13(3), 321-349. https://doi.org/10.1016/S0922-1425(01)00065-2

Lee Kiseok, Ni Shawn, and Ratti A Ronald. (1995). Oil Shocks and the Macroeconomy: the Role of Price Variability. The Energy Journal, 16(4), 39-56. https://doi.org/10.5547/ISSN0195-6574-EJ-Vol16-No4-2

Lee Yen-Hsien, and Chiou Jer-Shiou. (2011). Oil Sensitivity and its Asymmetric Impact on the Stock Market. Energy, 36(1), 168-174.

https://doi.org/10.1016/j.energy.2010.10.057

Lescaroux François, and Mignon Valérie. (2008). On the Influence of Oil Prices on Economic Activity and Other Macroeconomic and Financial Variables. OPEC Energy Review, 32(4), 343-380. https://doi.org/10.1111/j.1753-0237.2009.00157.x

Li Su-Fang, Zhu Hui-Ming, and Yu Keming. (2012). Oil Prices and Stock Market in China: A Sector Analysis using Panel Cointegration with Multiple Breaks. Energy Economics, 34(6), 1951-1958. https://doi.org/10.1016/j.eneco.2012.08.027

Lintner John. (1975). The Valuation of Risk Assets and the Selection of Risky Investments in Stock Portfolios and Capital Budgets. Stochastic Optimisation Models in Finance, 131-155.

Ma Feng, Wei Yu, Huang Dengshi, and Zhao Lin. (2013). Cross-correlations between West Texas Intermediate Crude Oil and the Stock Markets of the BRIC. Physica A: Statistical Mechanics and its Applications, 392(21), 5356-5368. https://doi.org/10.1016/j.physa.2013.06.061

Maghyereh Aktham. (2006). Oil Price Shocks and Emerging Stock Markets: A Generalized VAR Approach Global Stock Markets and Portfolio Management (pp. 55-68): Springer. https://doi.org/10.1057/9780230599338 5

Malik Farooq, and Ewing T Bradley. (2009). Volatility Transmission between Oil Prices and Equity Sector Returns. International Review of Financial Analysis, 18(3), 95-100. https://doi.org/10.1016/j.irfa.2009.03.003

Malkiel G Burton, and Fama F Eugene. (1970). Efficient Capital Markets: A Review of Theory and Empirical Work. The Journal of Finance, 25(2), 383-417. https://doi.org/10.1111/j.1540-6261.1970.tb00518.x

Merton C Robert. (1973). An Intertemporal Capital Asset Pricing Model. Econometrica: Journal of the Econometric Society, 41(5), 867-887. https://doi.org/10.2307/1913811

Miller J Isaac, and Ratti A Ronald. (2009). Crude Oil and Stock Markets: Stability, Instability, and Bubbles. Energy Economics, 31(4), 559-568. https://doi.org/10.1016/j.eneco.2009.01.009

Mohanty K Sunil, and Nandha Mohan. (2011). Oil Risk Exposure: The Case of the US Oil and Gas Sector. Financial Review, 46(1), 165-191. https://doi.org/10.1111/j.1540-6288.2010.00295.x

Mohanty Sunil, Nandha Mohan, and Bota Gabor. (2010). Oil Shocks and Stock Returns: The Case of the Central and Eastern European (CEE) Oil and Gas Sectors. Emerging Markets Review, 11(4), 358-372. https://doi.org/10.1016/j.ememar.2010.06.002

Mork K Anton. (1989). Oil and the Macroeconomy when Prices go Up and Down: An Extension of Hamilton's Results. Journal of Political Economy, 97(3), 740-744. https://doi.org/10.1086/261625

Mork, K Anton, Olsen Øystein, and Mysen H Terje. (1994). Macroeconomic Responses to Oil Price Increases and Decreases in Seven OECD Countries. The Energy Journal, 15(4), 19-35. https://doi.org/10.5547/ISSN0195-6574-EJ-Vol15-No4-2

Morrell Peter, and Swan William. (2006). Airline Jet Fuel Hedging: Theory and Practice. Transport Reviews, 26(6), 713-730. https://doi.org/10.1080/01441640600679524

Moya-Martínez Pablo, Ferrer-Lapeña Román, and Escribano-Sotos Francisco. (2014). Oil Price Risk in the Spanish Stock 
Market: An Industry Perspective. Economic Modelling, 37, 280-290.

https://doi.org/10.1016/j.econmod.2013.11.014

Nandha Mohan, and Faff Robert. (2008). Does Oil Move Equity Prices? A Global View. Energy Economics, 30(3), 986-997. https://doi.org/10.1016/j.eneco.2007.09.003

O'Neill T J, Penm Jack, \& Terrell, R Deane. (2008). The Role of Higher Oil Prices: A case of Major Developed Countries Research in Finance (pp. 287-299): Emerald Group Publishing Limited. https://doi.org/10.1016/S0196-3821(07)00211-0

Ogiri I Henry, Amadi S N, Uddin M Moshfique, and Dubon P. (2013). Oil Price and Stock Market Performance in Nigeria: An Empirical Analysis. American Journal of Social and Management Sciences, 4(1), 20-41.

Papapetrou Evangelia. (2001). Oil Price Shocks, Stock Market, Economic Activity and Employment in Greece. Energy Economics, 23(5), 511-532. https://doi.org/10.1016/S0140-9883(01)00078-0

Park Jungwook, and Ratti A Ronald. (2008). Oil Price Shocks and Stock Markets in the US and 13 European Countries. Energy Economics, 30(5), 2587-2608. https://doi.org/10.1016/j.eneco.2008.04.003

Perdiguero-García Jordi. (2013). Symmetric or Asymmetric Oil Prices? A Meta-analysis approach. Energy policy, 57, 389-397.

https://doi.org/10.1016/j.enpol.2013.02.008

Pesaran M Hashem, Shin Yongcheol, and Smith J Richard. (2001). Bounds Testing Approaches to the Analysis of Level Relationships. Journal of Applied Econometrics, 16(3), 289-326. https://doi.org/10.1002/jae.616

Ross Steven. (2013). The Arbitrage Pricing Theory of Capital Asset Pricing (Vol. Part I): World Scientific. https://doi.org/10.1142/9789814417358_0001

Sadorsky Perry. (1999). Oil Price Shocks and Stock Market Activity. Energy Economics, 21(5), 449-469. https://doi.org/10.1016/S0140-9883(99)00020-1

Sadorsky Perry. (2001). Risk Factors in Stock Returns of Canadian Oil and Gas Companies. Energy Economics, 23(1), 17-28. https://doi.org/10.1016/S0140-9883(00)00072-4

Sahu Tarak Nath, and Mondal Debasish. (2015). Crude Oil Price, Exchange Rate and Emerging Stock Market: Evidence from India. Jurnal Pengurusan, 42, 75-87.

Salisu A Afees, and Oloko F Tirimisiyu. (2015). Modeling Oil PriceUS Stock Nexus: A VARMA-BEKK-AGARCH Approach. Energy Economics, 50, 1-12. https://doi.org/10.1016/j.eneco.2015.03.031

Sari Ramazan, Hammoudeh Shawkat, and Soytas Ugur. (2010). Dynamics of Oil Price, Precious Metal Prices, and Exchange Rate. Energy Economics, 32(2), 351-362. https://doi.org/10.1016/j.eneco.2009.08.010
Scholtens Bert, and Yurtsever Cenk. (2012). Oil Price Shocks and European Industries. Energy Economics, 34(4), 1187-1195. https://doi.org/10.1016/j.eneco.2011.10.012

Sedick Afiefa. (2016). An Analysis of the Impact of Crude Oil Price Shocks on the Exchange Rate in South Africa. (MCom Economics ), University of the Western Cape.

Shammas Elie. (2012). The Impact of Oil Price Shocks on the Stock Return in Emerging Markets: Evidence from the BRICS Group. The Arab Academy for Banking and Financial Services Damascus, Syria. https://doi.org/10.2139/ssrn.2542336

Sharenet JSE. (2018). Quick share - Sharenet Retrieved from https://www.sharenet.co.za

Sharpe F William. (1964). Capital Asset Prices: A Theory of Market Equilibrium under Conditions of Risk. The Journal of Finance, 19(3), 425-442. https://doi.org/10.1111/j.1540-6261.1964.tb02865.x

Shin Yongcheol, Yu Byungchul, and Greenwood-Nimmo Matthew. (2014). Modelling Asymmetric Cointegration and Dynamic Multipliers in a Nonlinear ARDL Framework Festschrift in Honor of Peter Schmidt (pp. 281-314): Springer. https://doi.org/10.1007/978-1-4899-8008-3 9

Stulz RenéM. (1981). A Model of International Asset Pricing. Journal of Financial Economics, 9(4), 383-406. https://doi.org/10.1016/0304-405X(81)90005-2

Sukati Mphumuzi. (2013). Cointegration Analysis of Oil Prices and Consumer Price Index in South Africa using STATA Software. Munich Personal RePEc Achive, https://mpra.ub.uni-muechen.de/id.eprint/49797

Tang Weiqi, Wu Libo, and Zhang, ZhongXiang. (2010). Oil Price Shocks and their Short- and Long-term Effects on the Chinese Economy. Energy Economics, 32, S3-S14. https://doi.org/10.1016/j.eneco.2010.01.002

Vacha Lukas, and Barunik Jozef. (2012). Co-movement of Energy Commodities Revisited: Evidence from Wavelet Coherence Analysis. Energy Economics, 34(1), 241-247. https://doi.org/10.1016/j.eneco.2011.10.007

Wong SH Victor, and El Massah Suzanna. (2017). Recent Evidence on the Oil Price Shocks on Gulf Corporation Council Stock Markets. International Journal of the Economics of Business, 25(2), 297-312. https://doi.org/10.1080/13571516.2017.1379216

Zhang Chuanguo, and Chen Xiaoqing. (2011). The Impact of Global Oil Price Shocks on China's Stock Returns: Evidence from the ARJI (-ht)-EGARCH Model. Energy, 36(11), 6627-6633. https://doi.org/10.1016/j.energy.2011.08.052

Zhu Hui-Ming, Li Su-Fang, and Yu Keming. (2011). Crude Oil Shocks and Stock Markets: A Panel Threshold Cointegration Approach. Energy Economics, 33(5), 987-994. https://doi.org/10.1016/j.eneco.2011.07.002

\section{DOI: https://doi.org/10.6000/1929-7092.2020.09.34}

() 2020 Zengeni and Molele; Licensee Lifescience Global.

This is an open access article licensed under the terms of the Creative Commons Attribution Non-Commercial License (http://creativecommons.org/licenses/by-nc/3.0/) which permits unrestricted, non-commercial use, distribution and reproduction in any medium, provided the work is properly cited. 